Article

\title{
Gender Attitudes in Religious Schools: A Comparative Study of Religious and Secular Private Schools in Guatemala
}

\author{
Darin M. Mather
}

Social Sciences Department, Crown College, 8700 College View Drive, St. Bonifacius, MN 55375, USA; matherd@crown.edu

Received: 11 June 2018; Accepted: 19 July 2018; Published: 20 July 2018

\begin{abstract}
This study assesses the effect that private religious schools have on gender attitudes in students. Using data collected from twenty-one private schools in Guatemala, gender attitudes are assessed using latent class analysis. The results indicate that students' gender attitudes can be categorized into three distinct profiles. These are non-egalitarian, publicly egalitarian, and generally egalitarian. Subsequent analysis reveals that religious schools and specific religious beliefs are correlated with different gender attitude profiles. For instance, Catholic school students are more likely to be generally egalitarian than students in evangelical or secular schools, and biblical literalists are most likely to be publicly egalitarian. Overall, this research highlights the need to develop new conceptual models to provide more accurate and nuanced descriptions of gender attitudes. It also provides new insight into correlations between religious schools and religious beliefs and gender attitudes formation.
\end{abstract}

Keywords: religious education; gender attitudes; Catholic schools; evangelical schools; secular schools; Guatemala; Latin America; Latent Class Analysis

\section{Introduction}

Attitudes about gender roles have a significant impact on the private and public lives of both women and men. They affect family systems, labor force involvement, and political participation. Although a variety of different factors influence the formation of gender attitudes, two key socializing institutions are often associated with opposite effects. Schools are widely cited as promoting gender egalitarianism by regularly exposing students to egalitarian perspectives (Davis 2007). Religious institutions, on the other hand, are commonly linked to traditionalist ideologies in the literature (Nussbaum 2000). These competing visions of egalitarianism and traditionalism are juxtaposed in interesting ways in religious schools. Will students who attend religious schools become more egalitarian through educational exposure or more traditional through religious exposure? This question, which has not previously been explored in the literature, is the focus of the following study. I will seek to determine whether students from private Catholic, evangelical, and secular schools in Guatemala differ in their gender ideologies. The results will provide new insights into the relationship between religion and gender attitude formation.

\section{Theoretical Background}

\subsection{The Importance of Gender Attitudes}

Gender attitudes, which some researchers refer to as gender ideologies, are internalized prescriptive cultural beliefs about gender roles and values (Gibbons et al. 1997; Levant et al. 2007). 
A large body of research has demonstrated that gender attitudes are important because they are associated with a number of key outcomes inside and outside the home. First, they affect people's domestic lives. Gender egalitarianism is correlated, in both women and men, with delayed entry into marriage and marital childbearing (Cunningham et al. 2005). Once families are formed, egalitarian attitudes in husbands or wives or both are positively related to a more equitable distribution of household labor (Blair and Lichter 1991; Greenstein 1996; Kamo 1988). While this effect is consistent across cultures, the micro-level influence of gender attitudes on domestic labor distribution may be partially mediated by macro-level factors such as economic development, female labor-force participation, and welfare regimes in less egalitarian societies (Fuwa 2004).

The impact of gender attitudes also extends outside the home to employment, politics, and education. First, it affects labor force participation and earnings (see Rodríguez and Pillai (2017) for a review). Women who understand the female role as being mainly centered in the domestic realm are less likely to participate in paid employment (Thornton et al. 1983), with some believing that women's outside employment can have harmful effects on children (Ruiz et al. 2017). Alternatively, women with more egalitarian attitudes work more hours and have higher hourly earnings than those with less egalitarian attitudes (Corrigall and Konrad 2007).

Next, gender attitudes have a strong influence on female political participation. Ideas about women's role in society can enhance or constrain their political opportunities (Paxton and Kunovich 2003). In fact, gender ideology is often cited as the most common reason for low female political participation (Inter-Parliamentary Union IPU; Paxton and Hughes 2015).

Finally, and most germane to this study, gender attitudes have an effect on education. Girls with more egalitarian attitudes have higher self-esteem (Ossana et al. 1992; Mather 2015b) and more self-confidence in their math and science abilities (Grieve et al. 1988). Gender attitudes also affect girls' educational attainment. This is because girls' perceptions about the future and the roles that they may one day fulfill often lead them to have either higher or lower educational aspirations (Tallichet and Willits 1986; Cunningham et al. 2005; McDaniel 2010; Mather 2015a).

Because gender attitudes are correlated with so many important outcomes and because, as we will see below, schools have a significant effect on gender attitude formation, it is important to determine whether religious schools have different outcomes for gender formation than non-religious schools. Before we turn to this analysis, however, we must examine the ways in which gender attitudes are formed.

\subsection{The Formation of Gender Attitudes}

Bolzendahl and Myers (2004) suggest that most theoretical explanations for gender attitudes are a function of either interest-based or exposure-based issues. Interest-based theories contend that those who benefit directly from a gender egalitarian ideology are more likely to hold feminist attitudes. On the other hand, exposure-based theories argue that change in gender attitudes results from exposure to ideas and situations that bolster feminist ideas.

From an interest-based perspective, it is no surprise that gender is a key predictor for egalitarian attitudes. Although research indicates that both women and men benefit from gender equality (Barnett and Rivers 2004), women are more likely to hold to egalitarian ideologies because they are more likely to perceive tangible benefits for themselves in the form of economic gain, prestige, and self-actualization (Davis 2007; Davis and Greenstein 2009).

While interest-based factors are clearly important, exposure-based predictors, which emphasize gender socialization, receive the most attention in this study. Four key socializing influences are considered in the analysis below: home, education, national culture, and religion.

Children's attitudes are strongly shaped by their home environments. Parents' gender ideologies are transferred to their children through daily interactions, through modeling, and through the structuring of the home environment (Sutfin et al. 2008). Two key factors have particular influence. First, because there is a strong relationship between education and gender egalitarian perspectives 
(Bolzendahl and Myers 2004), parents' education levels can affect the gender attitudes of their children (Thornton et al. 1983; Tallichet and Willits 1986; Fan and Marini 2000). Maternal employment is another key factor. Working mothers often serve as egalitarian role models through their labor force participation. They are often exposed to more egalitarian perspectives in the workplace, and their increased responsibilities at work often foster a more egalitarian division of labor in the household. Each of these factors can influence children's gender attitudes (see Fan and Marini (2000); Davis (2007) for extensive reviews).

Education is a second strong socialization agent for gender equality. Those who are more educated tend to have more egalitarian gender attitudes (Tallichet and Willits 1986; Cunningham et al. 2005). This is because schooling tends to counter ideas about traditional male and female roles (Fan and Marini 2000), while supporting ideas of individual autonomy and merit-based achievement (Cunningham et al. 2005). Trend and panel studies consistently confirm that higher levels of education are correlated with increased gender egalitarianism (Davis 2007).

Third, children are socialized by their national culture. Different societies have different attitudes and expectations about appropriate gender roles. These varying gender ideologies affect the household division of labor, the institutional opportunities for women, and the female workforce and political participation rates within a given country (McDaniel 2010). While many in Guatemala-where this study was conducted - uphold egalitarian roles for women, machismo is still a relevant social force affecting broad swaths of the population, including those with high socioeconomic status and education levels (Gibbons et al. 2006).

Religion, a final important influence on gender attitudes, plays a key role in this study of religious schools. Many scholars contend that religion is adverse to gender equality and thus should be resisted or disregarded. Others view religion as a potential source for improving women's life situations (see Nussbaum (2000) for a review). This tension is particularly evident in Latin America, where scholars have uncovered evidence supporting both positions in this debate. Some scholars, such as Gill (1990), conclude that the Pentecostal religion that is growing rapidly in the region is detrimental to women because many Pentecostals view the subordination of women as part of the natural order that is sanctioned by God. On the other hand, a number of researchers, including Marquardt (2005); Mariz and Machado (1997); and Brusco (1993), have found that evangelicalism is often supportive of women's autonomy. This is because its emphasis on family life serves as an antidote to machismo, providing women with practical improvements in the form of respect and support from their husbands.

Quantitative studies of religion and gender in the United States have generally concluded that the religiously affiliated have less egalitarian attitudes than the non-affiliated and that Conservative Protestants are the least egalitarian (see Fan and Marini (2000) for a review). Among Latinas/os, Ruiz et al. (2017) found no significant difference between Catholics and the religiously unaffiliated, but they did find Conservative Protestants to be less egalitarian.

The literature on gender equity and religion also indicates that specific religious beliefs affect gender attitudes (See Davis and Greenstein (2009) for a review). The study by Steigenga and Smilde (1999) in Guatemala and Costa Rica found little difference overall between Protestants, Catholics, and the nonaffiliated in their attitudes toward women's rights in society. However, their analysis did find a significant link between certain religious beliefs and a respondent's attitudes toward gender equality. "Two measures of theological conservatism (responses concerning biblical literalism and Christ's death for our sins) had positive and significant effects on agreement with the statement that women should enjoy all the political rights and responsibilities that men do. One measure of millennialism (that Christ will return soon) had a negative and significant effect on agreement" (Steigenga and Smilde 1999, p. 180). These findings in Latin America run counter to results of studies in the United States in which, even among Latinas/os, biblical literalism is consistently correlated with more traditional gender ideologies, especially in regard to women's roles in the home and in religious institutions (Peek et al. 1991; Hoffman and Bartkowski 2008; Bartkowski and Hempel 2009; Ruiz et al. 2017). 
This literature demonstrates the complex nature of gender attitude formation, suggesting that many different factors play a role in its development. Many of these factors will be included in the models below, but before these models can be developed, we must examine the ways in which gender attitudes are measured.

\subsection{The Measurement of Gender Attitudes}

In the field of gender studies, there has been much debate about whether gender is a unidimensional or multidimensional concept. Though initially conceived unidimensionally as a masculine-feminine continuum, later scholarship concluded that it is best understood multidimensionally, including various perspectives on sex roles, identity, personality, and ideology (see Spence (1993); Spence and Buckner (2000); Levant et al. (2007) for examples of different constructions).

Research on gender attitudes has also engaged in debates about the dimensionality of gender equality. Here, too, unidimensional ideas-emphasizing a linear continuum from traditional to egalitarian-have given way to multidimensional conceptualizations (Milo et al. 1983). Though a number of different factors have been proposed, two factor models distinguishing between public and private gender attitudes have been shown to fit the data best (Milo et al. 1983; King et al. 1997; McDaniel 2008). The public dimension addresses gender attitudes related to politics, education, and the workplace. The private dimension emphasizes domestic attitudes such as who the breadwinner should be, the division of labor in the home, parent-child relationships, and family decision-making (King et al. 1997; McDaniel 2008).

While the private and public dimensions of gender attitudes have been recognized for some time, little, if any, research has sought to distinguish between respondents' attitudes in each of these dimensions. They are often considered separately, using scales that focus on either the public (Price 2008) or the private (Kaufman 2000) dimensions, or scales that lump the two together (Inglehart and Norris 2003; McDaniel 2008). However, few, if any, studies consider the distinctive influence of both dimensions. Is it possible for people to hold more egalitarian public gender attitudes while retaining traditional gender attitudes in the private sphere? Could it also happen the other way around?

In the pages that follow, I will demonstrate that these are important empirical distinctions to consider. I begin by using latent class analysis to examine patterns in public and private gender attitudes among Guatemalan private school students. Once these patterns are established, I use simple $t$-tests, along with more sophisticated hierarchical linear models, to determine which factors are most closely correlated with gender attitudes in these different domains.

\section{Methods}

\subsection{Data}

This paper draws on data collected from private Catholic, evangelical, and secular schools in Guatemala. Guatemala was selected for this project because a high percentage of its schools are private and religious. Ministry of Education data show that nearly $15 \%$ of elementary schools, $54 \%$ of middle schools, and $87 \%$ of high schools in Guatemala are private (MINEDUC 2007). More than $25 \%$ of these private schools are Catholic or evangelical (MINEDUC 2008). Guatemala became largely Christianized during the colonial era, and Catholicism dominated the religious and cultural landscape for centuries. This began to change in the twentieth century when Pentecostalism started to sweep across the globe (Cox 1995; Martin 1990). Although Pentecostalism made inroads throughout Latin America, it grew with particular speed in Guatemala, especially after the devastating earthquake in 1976 that killed 20,000 and left over a million homeless. Pentecostalism, which is often attractive to the destitute (Martin 2002; Mariz 1994), grew by 14\% in the months following the earthquake (Chozick 2002). This growth continued through the following decades, extending into the middle and upper classes of Guatemalan society. Today, Pentecostals, who are often called evangelicals, constitute nearly $40 \%$ of the 
total population (see Garrard-Burnett 1998; O'Neill 2010; Sherman 1997 for in-depth studies on the rise of evangelicalism and its impact on Guatemalan society)

In this context, 21 different private schools (seven Catholic, nine evangelical, and five secular) were studied to assess the gender attitudes in their schools. Secular institutions were included as a comparison group. The school sample was chosen from a list, provided by the Guatemalan Ministry of Education, of all schools in the Department of Sacatepequez, which lies just to the west of the capital city. Schools were selected for consideration if they were private and if they had students at the primary and junior levels (grades 1-10). Efforts were made to choose a similar number of urban and rural schools, and when possible, Catholic, evangelical, and secular schools were chosen from the same area in an attempt to include similar demographics in the sample. Schools were identified as Catholic, evangelical, or secular by the school administrator. While in some contexts, the distinction between Pentecostals and evangelicals is important, the two groups are often indistinguishable in many Latin American societies like Guatemala. In this study, I use the term evangelical to refer to conservative Protestant evangelical or Pentecostal schools, or to students who self-identify as evangelicals in their survey responses.

The data for this study were derived directly from surveys, which were administered to students, aged 10 to 15 , in grades 5 to 9 , of each school. In addition to gathering demographic information about the students' gender, ethnic, family, and religious background, the surveys also asked about students' gender attitudes and religious beliefs and values. Because the study posed minimal risk to the students and because, in the Guatemalan context, it is unusual (and nearly impossible) to get parental consent, the Institutional Review Board overseeing this study waived the parental consent requirement (Lokesh et al. 2013). Permission to distribute surveys was given by school administrators and classroom teachers. Students provided their written personal consent after hearing the purpose, procedures, and potential risks of the surveys plainly presented verbally and in written form. Students were not pressured to participate and were told they could just turn in a blank form at the end of the time period if they did not wish to complete a survey. All surveys were anonymous to further protect the students.

Using this survey data, I compare the gender attitudes of students in Catholic, evangelical, and secular private schools. This analysis has two parts. First, latent class analysis (LCA) is used to uncover patterns of gender attitudes among all students in the sample. Next, I use proportional tests and hierarchical linear models (HLM) to determine which gender attitude formation predictors are associated with the resulting gender attitude outcomes for students in each type of private school.

\subsection{Latent Class Analysis}

As the literature review indicates above, most research on gender attitudes is conducted using scales derived from a list of survey responses assessing public and private gender attitudes. While this approach is helpful, it does not uncover the patterns in survey responses that could reveal underlying dimensions in these attitudes. Other studies use factor analysis to uncover different patterns of gender attitudes, but the analysis usually stops there. These factors are rarely mobilized to determine which gender attitude formation predictors and demographic features are associated with the established dimensions.

I take a different approach by using LCA to find compositional patterns in gender attitude responses. LCA, which has been used elsewhere to provide fuller, more nuanced descriptions than traditional scalar methods (Edgell et al. 2013), is a statistical method that seeks to determine whether a set of unobserved classes can account for associations among indicator variables (McCutcheon 1987; Silverstein and Bengston 1997). It divides the cases into different latent classes that are conditionally independent, meaning that the variables of interest are uncorrelated with other variables within any given class. The resulting classes are not observed directly from the data; rather, they are identified based on patterns of relationships found among the survey indicators-in this case, variations in gender attitudes. 
LCA is somewhat analogous to factor analysis, which has been used before to ascertain different dimensions of gender attitudes. Both methods seek to infer unobserved constructs from observed data; however, there are two important differences between the two. First, LCA is most concerned with case patterns, while factor analysis focuses on patterns in the variables. Second, unlike factor analysis, LCA assigns cases to specific latent class groups. This allows for further analysis of predictors and outcomes for the members assigned to these groups-something that is more difficult to do with factor analysis.

Two types of parameters are estimated in LCA analysis. The latent class probabilities identify the prevalence of each latent class. While this parameter can be thought of as the percentage of cases in each latent class, a more accurate analogy would be a mixture or density model, such that each respondent contributes some information to each latent class. The conditional item probabilities are specific to a given class and are the probabilities of observing that specific characteristic in each latent class (McCutcheon 1987; Vermunt 2010). Maximum likelihood estimation in Latent Gold 5.0 was used to maximize the log-likelihood function specified by Vermunt and Magidson (2004).

The fit of a specific number of latent classes to the data is determined using several statistics (Vermunt and Magidson 2005). The log-likelihood (LL) chi-square statistic assesses goodness of fit by estimating the proportion of classification errors. Next, the Bayesian information criteria (BIC) is used to differentiate between proposed models containing a varying number of latent classes. Finally, the Akaike information criterion (AIC) is used to find the most parsimonious model. In general, lower values for LL, BIC, and AIC parameters suggest a better fit. One last criterion that can be used to determine the best number of latent classes is the $p$-value for each model under the assumption that the LL statistic follows a chi-square distribution. Generally, for models with $p$-values greater than 0.05 , the one with the fewest parameters is the best.

\subsection{Proportional Tests and HLM to Assess Predictors of Gender Attitudes}

After patterns of gender attitudes have been determined using LCA, the next step is to ascertain which factors are associated with each of the established profiles. I begin this analysis with simple proportional tests to compare outcomes for Catholic, evangelical, and secular schools. Because Catholic schools are not exclusive to Catholic students and evangelical schools are not exclusive to evangelical students, I have included analysis that shows the specific impact of each of these schools on students from varying religious traditions.

Next, I develop multivariate models to assess correlations between religious schools and gender attitudes when controls for students' gender, grade, family background, and religious beliefs are added. Because the students in these surveys are clustered in 21 schools, responses for students from the same school are likely correlated. For this reason, multilevel models are more appropriate than traditional ordinary least square methods. Multilevel methods minimize distortion in estimates that could be caused by intraschool correlations by partitioning error variances into between-school and within-school components (Raudenbush and Bryk 2002). In this way, between-school effects-such as school type-and within-school effects—-such as students' gender, grade, family background, and religious beliefs-can be assessed simultaneously. Separate logit models are created to assess correlations of the independent variables with each of the gender attitude profiles that are uncovered through LCA. Hausman tests determined that random-effects models are most appropriate for analyzing differences between these school clusters. Tests were also conducted to ensure that independent variables are not highly correlated, and results for each model have been checked to ensure that outliers do not have an undue impact on coefficients. 


\section{Results}

\subsection{Patterns of Gender Attitudes}

In this study, four different variables, which are listed in Table 1, are used to measure students' gender attitudes. The first variable, suggesting that the man should be the head of the household, assesses gender attitudes in the home. The last two relate to women's roles in the economic and political realms. The second variable, suggesting that men are better leaders than women, could apply to the private or public domains. Dummy variables, reoriented from their original wording to assess gender egalitarianism, were created to ease interpretation. Those who strongly agreed or strongly disagreed, depending on the question, were coded as 1.

Table 1. Descriptive Summary of Variables Measuring Gender Attitudes.

\begin{tabular}{lcc}
\hline \multicolumn{1}{c}{ Variable } & Mean & $\%{ }^{*}$ \\
\hline $\begin{array}{c}\text { The man should be the head of the family. } \\
(4=\text { strongly agree; } 1 \text { = strongly disagree })\end{array}$ & 2.61 & $\begin{array}{c}13.16 \% \\
\text { strongly disagree }\end{array}$ \\
\hline $\begin{array}{c}\text { The majority of men are better leaders than women. } \\
(4=\text { strongly agree; } 1 \text { = strongly disagree })\end{array}$ & 2.20 & $\begin{array}{c}20.78 \% \\
\text { strongly disagree }\end{array}$ \\
\hline $\begin{array}{l}\text { Women can do the same jobs as men. } \\
(4=\text { strongly agree; } 1 \text { = strongly disagree })\end{array}$ & 3.12 & $\begin{array}{c}39.50 \% \\
\text { strongly agree }\end{array}$ \\
\hline $\begin{array}{c}\text { Someday I would like to see a woman as president of our country. } \\
(4=\text { strongly agree; } 1 \text { = strongly disagree })\end{array}$ & 3.57 & $\begin{array}{c}61.10 \% \\
\text { strongly agree }\end{array}$ \\
\hline
\end{tabular}

The model fit statistics for the LCA are presented in Table 2. Based on the indicators described above, the model that best fits the data while maintaining parsimony is the three latent class model. This is an important finding. Had the results indicated that just one latent class is the best fit for the data, it would suggest that traditional scalar (unidimensional) methods are most appropriate. However, the three class finding demonstrates that variations in the data are best represented by multiple dimensions.

Table 2. Latent Class Model Fit.

\begin{tabular}{ccccccc}
\hline Number of Classes & \# of Parms. & df & LL & BIC & AIC & Bootstrapped $\boldsymbol{p}$-Value \\
\hline 1 & 4 & 11 & 479.690 & 398.084 & 457.690 & 0.000 \\
2 & 9 & 6 & 56.730 & 12.217 & 44.729 & 0.000 \\
3 & 14 & 1 & 6.530 & -0.886 & 4.532 & 0.072 \\
4 & 19 & -4 & 0.820 & 30.494 & 8.819 & 0.214 \\
5 & 24 & -9 & 0.039 & 66.810 & 18.040 & 0.448 \\
\hline
\end{tabular}

BIC—Bayesian information criterion; AIC—Akaike information criterion; $\mathrm{df}$ - degrees of freedom.

These dimensions are detailed in Table 3. The column headers at the top of the table describe the three latent classes that were derived from the LCA. I have named these classes non-egalitarian, publicly egalitarian, and generally egalitarian. These labels describe the distinct differences that I observe in the three classes. Listed below the headers is the cluster size. This shows that roughly half the students surveyed fit the publicly egalitarian profile. Less than one-third are generally egalitarian. The smallest class is the non-egalitarian class. 
Table 3. Latent Class Analysis Profiles.

\begin{tabular}{lccc}
\hline & Non-Egalitarian & Publicly Egalitarian & Generally Egalitarian \\
\hline Cluster Size & 0.130 & 0.540 & 0.319 \\
\hline Indicators: & & \\
\hline \multicolumn{1}{l}{ The Man Is Not the Head of Family } & & \\
\hline 0 & 0.892 & 0.767 & 0.112 \\
1 & 0.108 & 0.233 & \\
\hline Men Are Not Better Leaders Than Women & & 0.032 \\
\hline 0 & 0.858 & 0.968 \\
1 & 0.142 & 0.442 & 0.205 \\
\hline Women Can Do the Same Jobs as Men & & 0.795 \\
\hline 0 & 0.623 & 0.296 & \\
1 & 0.377 & 0.704 & 0.085 \\
\hline Would Like to See a Female President & & 0.915 \\
\hline 0 & 0.766 & 0.005 & \\
\hline
\end{tabular}

The last portion of the table provides information about the observed indicator variables and the ways they are patterned in the latent classes. Each of the gender attitude variables from Table 1 is listed along with the probabilities of observing that specific characteristic in each latent class ( 1 indicates strongly agreeing with the statement). In the "Non-Egalitarian" column, there is a probability of 0.108 that a respondent in this class would strongly agree that "the man is not the head of the family" and a probability of 0.892 that respondents in this class would not strongly agree. This output reveals the following patterns of responses for each latent class.

The first thing to note is that two of the latent classes are diametric opposites. On the one hand, non-egalitarians, the smallest of the classes, hold more traditional gender attitudes across the board. They are quite likely to affirm that men should be the head of the family and that men are better leaders than women. They are also likely to disagree that women can do the same jobs as men and that they would like to see a woman as president. On the other end of the spectrum, a larger group of students fit the profile I call generally egalitarian. They are very likely to affirm egalitarian gender roles in each of the survey items. These opposing gender viewpoints fit well with the literature that contrasts traditionalist attitudes with those that are more egalitarian (Paxton and Kunovich 2003).

The publically egalitarian profile, however, adds something new to the mix. While it is probably not surprising that the largest group of respondents lies somewhere between the extremes of the non-egalitarian and generally egalitarian profiles, it is interesting to note that the members of this class tend to follow a very specific pattern. In the public domain, members of this class are just as affirming of egalitarian attitudes as those in the generally egalitarian profile. They broadly support gender equality in the workplace and in politics. In the private domain, however, they tend to be much more traditional. People in this profile are evenly divided on whether or not men are better leaders than women because this survey question is ambiguous as to whether it applies to the public or private realms. This profile is distinctive in the literature in that it specifically identifies a set of gender attitudes that are simultaneously publicly progressive and privately traditional. As we will see in the analyses that follow, a publicly egalitarian profile opens new conceptual space for comparisons of gender attitudes and the factors that predict them.

\subsection{Effect of Religious Schools}

Having established the gender attitude profiles, I will next seek to determine which factors are correlated to each profile. The first and most central question for this study is whether students from 
secular schools have more egalitarian attitudes than students from religious schools. I begin examining this question with simple $t$-tests. Table 4 below displays the results of the one sample proportional tests.

The top line of the table provides the sample proportions for each of the gender attitude profiles. These proportions serve as reference points for the rest of the results in the table. Each section of the table begins with findings for each type of school followed by results for students from the corresponding religious tradition. Because students from various religious traditions attend each type of school, I have also included output for students from each religious tradition who attend each type of school.

The results in Table 4 only partially affirm expectations that secular schools will be more egalitarian than Catholic and evangelical schools. According to these results, secular schools are indeed more egalitarian than evangelical schools, but the most egalitarian are clearly Catholic schools. Students in Catholic schools are significantly below the sample mean percent for publically egalitarian, but they are nearly nine percentage points above the mean percent for generally egalitarian. These findings are strongly supported by comparisons between different religious subgroups who attend Catholic schools. Catholic students in Catholic schools are among the lowest of all subgroups in adherence to public egalitarianism, and they are among the highest in general egalitarianism. Interestingly though, students in Catholic schools do not tend to be less non-egalitarian than the wider sample. In fact, "other" students (those not affiliated with the Catholic or evangelical church) who attend Catholic schools are more non-egalitarian by a significant margin. ${ }^{1}$ Based on these findings, we can generally say that students in Catholic schools are the most generally egalitarian of all private student groups in this region of Guatemala, and as a result, they tend to be less publically egalitarian than others.

Table 4. Crosstab Comparison of Gender Attitudes between Religious Schools.

\begin{tabular}{|c|c|c|c|c|}
\hline & $N$ & Non-Egalitarian & Publically Egalitarian & Generally Egalitarian \\
\hline Catholic School & 724 & $12.71 \%$ & $46.41 \% * * *$ & $40.47 \%$ *** \\
\hline Catholic Student in Catholic School & 613 & $11.58 \%$ & $47.31 \% * * *$ & $40.78 \% * * *$ \\
\hline Catholic Student in Evangelical School & 211 & $9.95 \%$ & $57.35 \%$ & $30.81 \%$ \\
\hline Catholic Student in Secular School & 161 & $4.97 \%$ ** & $64.60 \%$ ** & $30.43 \%$ \\
\hline Evangelical Student & 525 & $16.19 \%$ * & $59.05 \%$ * & $23.24 \% * * *$ \\
\hline Evangelical Student in Evangelical School & 365 & $18.08 \%$ ** & $58.90 \%$ * & $21.37 \% * * *$ \\
\hline Evangelical Student in Catholic School & 77 & $14.29 \%$ & $48.05 \%$ & $36.36 \%$ \\
\hline Evangelical Student in Secular School & 83 & $9.64 \%$ & $69.88 \% * *$ & $19.28 \%$ ** \\
\hline Secular School & 296 & $8.45 \%$ ** & $64.19 \% * * *$ & $27.03 \%$ * \\
\hline Other Student & 165 & $19.39 \%$ ** & $50.30 \%$ & $29.70 \%$ \\
\hline
\end{tabular}

Significantly different from sample mean at ${ }^{*} p<0.05$; $^{* *} p<0.01 ;{ }^{* * *} p<0.001$ (two-tail test).

In contrast, students in evangelical schools are significantly more likely to be non-egalitarian or publically egalitarian and significantly less likely to be generally egalitarian than the sample mean. Evangelicals who go to evangelical schools are among the highest in their support for non-egalitarianism. ${ }^{2}$ They are significantly higher than the sample proportion in public egalitarianism and they are among the lowest in general egalitarianism-10 percentage points below the sample mean. Catholic students who attend evangelical schools also tend to be more publically egalitarian and less generally egalitarian than other Catholic students. The same holds for students attending evangelical

1 It is difficult to speculate about why this result is so high without learning more about the students who make up this "other" group.

2 "Other" students are higher, but again these comparisons are difficult because the survey provides no information about these students' religious affiliations. 
schools who are not affiliated with Catholic or evangelical churches. These subgroup findings strongly support the broad picture for students attending evangelical schools. They are significantly more likely to be non-egalitarian and significantly less likely to be generally egalitarian than the wider student population. The majority of evangelical students support public egalitarianism.

Students who attend secular schools tend to occupy a middle ground between Catholic and evangelical students. They are among the least likely to adhere to non-egalitarianism, but they are much less likely to be generally egalitarian than Catholic school students. Secular school students are by far the most likely to hold to public egalitarianism. This pattern clearly holds when comparisons are made between Catholics and evangelicals who attend secular schools and the wider populations of Catholic and evangelical students.

\subsection{Religious and Nonreligious Effects on Gender Attitudes}

The last analytical step is to create broader models to assess which religious and nonreligious factors significantly affect gender attitudes. The findings from the $t$-tests above are expanded to determine whether the patterns of difference between school types uncovered in the preceding section will hold when religious and nonreligious controls are added. In the hierarchical linear models that follow, I incorporate various independent variables to measure the effect of factors that have previously been shown to influence gender attitudes. These variables are listed in Table 5, which provides descriptive statistics for the full sample along with separate findings for Catholic, evangelical, and secular schools.

Table 5. Descriptive Statistics of Independent Variables in Gender Attitude Models.

\begin{tabular}{|c|c|c|c|}
\hline Independent Variable & Description of Variable & $\begin{array}{c}\text { Sample } \\
\text { Mean or \% }\end{array}$ & $\begin{array}{l}\text { Cath. Schl. } \\
\text { Mean or \% }\end{array}$ \\
\hline Catholic school & Student goes to Catholic school. & $43.10 \%$ & $100.00 \%$ \\
\hline Evangelical school & Student goes to evangelical school. & $39.30 \%$ & $0.00 \%$ \\
\hline Catholic student & Student identifies self as Catholic. & $58.90 \%$ & $85.04 \%$ \\
\hline Evangelical student & Student identifies self as evangelical. & $31.36 \%$ & $10.66 \%$ \\
\hline Cath. student in Cath. school & Student is Catholic going to a Catholic school. & $36.68 \%$ & \\
\hline Evan. student in evan. school & Student is evangelical going to an evangelical school. & $21.80 \%$ & \\
\hline Female student & Student identifies as female. & $50.33 \%$ & $54.13 \%$ \\
\hline Student grade level & Student's grade in school (Ranges 5-9) & $\begin{array}{c}7.09 \\
(1.41)\end{array}$ & $\begin{array}{c}7.06 \\
(1.40)\end{array}$ \\
\hline Mother's education & $\begin{array}{l}\text { Mother's education } \\
0=\text { did not complete primary school; } \\
1 \text { = completed primary school; } \\
2 \text { = completed middle school; } \\
3 \text { = completed secondary school; } \\
4 \text { = attended university }\end{array}$ & $\begin{array}{c}2.03 \\
(1.42)\end{array}$ & $\begin{array}{c}1.96 \\
(1.37)\end{array}$ \\
\hline Mother is a homemaker & Student's mother is a homemaker. & $38.05 \%$ & $37.01 \%$ \\
\hline Biblical literalism & $\begin{array}{l}\text { Student strongly agrees that the Bible is inspired by God and } \\
\text { must be accepted literally word for word. }\end{array}$ & $67.36 \%$ & $63.86 \%$ \\
\hline Christ returns soon & $\begin{array}{l}\text { Student strongly agrees that Christians should not be } \\
\text { concerned about this world because Christ will return soon to } \\
\text { establish his kingdom. }\end{array}$ & $42.75 \%$ & $36.00 \%$ \\
\hline Church decides morals & $\begin{array}{l}\text { Student strongly agrees that the church should play a key role } \\
\text { in deciding what is right or wrong in our societies. }\end{array}$ & $35.79 \%$ & $38.62 \%$ \\
\hline dard deviation in parenth & & & \\
\hline
\end{tabular}

Aside from the school variables, I have included controls for the religious tradition of the students. Because they were regularly significant in Table 4, I have also included interactions for Catholic students in Catholic schools and evangelical students in evangelical schools. Additionally, the models include a female dummy and a grade level variable to assess whether females and older students are associated with different gender profiles. Homemaker and mother's education variables have been 
included to determine if less traditional and better educated mothers may impact a student's gender profile. Finally, three theological variables, which have previously been associated with varying levels of egalitarianism, have been added to test the effect of specific religious beliefs. ${ }^{3}$

Table 6 below provides the results of multivariate HLM models for each of the three different profiles of gender attitudes. Because the dependent variables are dummies assessing whether students' gender attitudes fit a certain profile, logit models are used. The coefficients are displayed as odds ratios to ease interpretation. Any result that is greater than one indicates increased odds, whereas results less than one represent decreased odds.

The first step in the analysis is to examine correlations between school type and gender profile. Model 1 provides a direct comparison of Catholic, evangelical, and secular schools (secular is omitted as the reference category to illustrate the effect of religious schools). These findings closely mirror those in Table 4. However, when the controls are added in Model 2, we find a few variations in the results. First, while students in evangelical schools are significantly more likely to be non-egalitarian in the base model, this significance disappears in Model 2, indicating that school type is not the most important predictor. The publically egalitarian models show that, even when controls are added, students in Catholic schools remain significantly less publically egalitarian than secular school students. There is no statistically significant difference between evangelical and secular school students in this profile. Finally, the results show that, when controls are added, Catholic school students are twice as likely to be generally egalitarian than secular school students, while there is no significant difference between evangelical and secular school students. Overall, we see that students in Catholic schools tend to be less publically egalitarian and more generally egalitarian than secular school students, while there is no significant difference between students in evangelical and secular schools across the board. These findings negate notions that secular schools are more egalitarian than religious schools. In fact, all in all, students in Catholic schools appear to be the most egalitarian. Nothing in the data can specifically explain this difference, although the Catholic schools in my sample did tend to have more female teachers and administrators than other schools.

Student characteristics, specifically examining the effect of gender and grade, were also assessed. The full models show that female students are significantly less likely to be non-egalitarian, whereas they are significantly more likely to be generally egalitarian than the male students. This finding is not surprising and it confirms the theory that females' self-interest will make them more egalitarian than males (Davis 2007; Davis and Greenstein 2009).

The student grade variable follows the same pattern. Students in higher grades (both males and females) are significantly less likely to be non-egalitarian and significantly more likely to be generally egalitarian. This affirms the well-established findings in the literature that those with more education tend to be more egalitarian (Davis 2007). However, because these data are cross-sectional, it is not possible to determine if findings are directly attributable to a cumulative effect of exposure to schooling or to a specific type of schooling, or to other factors associated with childhood and adolescent development. This would be an important topic to consider in future studies.

3 A variable measuring commitment to the idea that Christ died for our sins was a significant indicator in Steigenga and Smilde's (1999) research. I have not included that variable in this analysis because there is very little variation in student responses ( $80.44 \%$ of all students in the sample strongly agreed with this statement) and because it was highly correlated with biblical literalism $(90.47 \%$ of students who strongly supported biblical literalism also strongly agreed that Christ died for our sins). 
Table 6. Gender Egalitarian Predictors Hierarchical Linear Models.

\begin{tabular}{|c|c|c|c|c|c|c|c|c|c|c|c|c|c|c|c|c|c|c|}
\hline & \multicolumn{6}{|c|}{ Non-Egalitarian } & \multicolumn{6}{|c|}{ Publicly Egalitarian } & \multicolumn{6}{|c|}{ Generally Egalitarian } \\
\hline & \multicolumn{3}{|c|}{ Model 1} & \multicolumn{3}{|c|}{ Model 2} & \multicolumn{3}{|c|}{ Model 1} & \multicolumn{3}{|c|}{ Model 2} & \multicolumn{3}{|c|}{ Model 1} & \multicolumn{3}{|c|}{ Model 2} \\
\hline & OR & & SE & OR & & $\mathrm{SE}$ & OR & & SE & OR & & SE & OR & & SE & OR & & SE \\
\hline Catholic school & 1.58 & & $(0.37)$ & 2.13 & & $(0.97)$ & 0.48 & $* * *$ & $(0.08)$ & 0.38 & $* *$ & $(0.12)$ & 1.83 & $* *$ & $(0.32)$ & 2.07 & $*$ & $(0.71)$ \\
\hline Evangelical school & 1.99 & $* *$ & $(0.47)$ & 1.23 & & $(0.44)$ & 0.77 & & $(0.12)$ & 0.92 & & $(0.19)$ & 0.88 & & $(0.16)$ & 0.95 & & $(0.22)$ \\
\hline Catholic student & & & & 0.35 & $* *$ & $(0.12)$ & & & & 1.44 & & $(0.32)$ & & & & 1.15 & & $(0.28)$ \\
\hline Evangelical student & & & & 0.44 & & $(0.20)$ & & & & 2.26 & $* *$ & $(0.68)$ & & & & 0.60 & & $(0.19)$ \\
\hline Cath. student in Cath. School & & & & 0.76 & & $(0.39)$ & & & & 1.37 & & $(0.48)$ & & & & 0.83 & & $(0.31)$ \\
\hline Evan. student in Evan. School & & & & 2.40 & & $(1.25)$ & & & & 0.57 & & $(0.19)$ & & & & 1.14 & & $(0.42)$ \\
\hline Female student & & & & 0.31 & $* * *$ & $(0.06)$ & & & & 1.08 & & $(0.13)$ & & & & 1.63 & $* * *$ & $(0.21)$ \\
\hline Student grade level & & & & 0.86 & * & $(0.06)$ & & & & 0.92 & & $(0.04)$ & & & & 1.19 & $* * *$ & $(0.05)$ \\
\hline Mother's education & & & & 1.07 & & $(0.07)$ & & & & 1.03 & & $(0.04)$ & & & & 0.93 & & $(0.04)$ \\
\hline Mother is a homemaker & & & & 1.03 & & $(0.20)$ & & & & 0.96 & & $(0.12)$ & & & & 1.04 & & $(0.14)$ \\
\hline Biblical literalism & & & & 0.60 & * & $(0.12)$ & & & & 1.30 & $*$ & $(0.17)$ & & & & 0.95 & & $(0.13)$ \\
\hline Christ returns soon & & & & 0.95 & & $(0.19)$ & & & & 1.21 & & $(0.15)$ & & & & 0.79 & & $(0.11)$ \\
\hline Church decides morals & & & & 0.73 & & $(0.15)$ & & & & 1.57 & $* * *$ & $(0.20)$ & & & & 0.69 & $* *$ & $(0.10)$ \\
\hline$N$ & 1678 & & & 1315 & & & 1678 & & & 1315 & & & 1678 & & & 1315 & & \\
\hline Wald chi-square & 8.90 & & & 76.11 & & & 26.89 & & & 64.39 & & & 29.43 & & & 87.64 & & \\
\hline
\end{tabular}

${ }^{*} p>0.05 ;{ }^{* *} p>0.10 ;{ }^{* * *} p>0.01$. 
Surprisingly, the full models register no effect from mother's education or the mother's being a homemaker. This unexpected result does not align with well-established links between mother's education and work status and children's gender attitudes (Fan and Marini 2000). Here, cultural differences may come into play. For some in Latin America, being a homemaker is somewhat of a status symbol, reflecting that the mother does not need to work to support the family. Also, much of women's employment in Guatemala is highly gendered, with many women working as cleaners, vendors, clerks, and teachers. The environments that these women work in may not socialize them in the same ways as Western contexts.

Finally, we examine the influence of specific student religious beliefs. First, findings indicate that those students who strongly agree that the Bible is inspired by God and must be accepted literally word for word are significantly less likely to be non-egalitarian and significantly more likely to be publicly egalitarian. This result partially affirms predictions that biblical literalists will be more egalitarian and it affirms the findings of Steigenga and Smilde (1999) that literalists will support female economic and political rights. Next, the results show that the "Christ returns soon" variable, which measures millennialist beliefs, is not a significant indicator for any of the gender profiles, negating the findings of Steigenga and Smilde. Finally, those students who strongly affirm that the church should play a key role in deciding what is right or wrong in society are significantly less likely to be generally egalitarian and significantly more likely to be publically egalitarian. This partially supports the prediction that students who strongly endorse church authority will be less egalitarian.

The broad picture painted by the findings for these religious belief variables is that students who strongly hold to the authority of the Bible and the church do not have a greater propensity to completely non-egalitarian attitudes. Instead, these students tend to support egalitarian roles for women in the public sphere, while embracing traditional roles for women in the home.

\section{Discussion}

The results of this study contribute to our understanding of gender attitudes in religious institutions in a number of important ways. First, it introduces a new method for studying gender attitudes. Most existing research relies heavily on unidimensional scales that do not effectively measure nuances in respondents' gender attitudes. Other studies use factor analysis to uncover various dimensions of gender attitudes, but these are often not deployed in analyses that predict which social factors are associated with each specific dimension (Cole and Zucker 2007). Latent class analysis allows researchers to uncover the various dimensions of gender attitudes, producing profiles that can be incorporated into analytical models as dependent or independent variables. This method has great potential for helping to improve our understanding of gender attitudes and should be employed in future research.

Using the latent class analytical approach, this study produced a new descriptive category for gender attitudes. Traditional scalar models emphasize that people's gender attitudes are non-egalitarian, completely egalitarian, or somewhere in between, but they do not specify the nature of the attitudes that lie "in between". This study's results reveal an additional distinct middle category that is widely affirmed by Guatemalan school children. Public egalitarians, who make up the majority of respondents in this study, tend to support women's equality in the economic and political spheres while maintaining traditional attitudes in the home. This new category incorporates two separate dimensions of gender attitudes that have previously been discussed in the literature, the public and the private (Milo et al. 1983; King et al. 1997), and it conceptualizes them in a new way. Many of those "in between" support gender equality in public, but not in the home. ${ }^{4}$ The fact that the publicly egalitarian profile describes more than half the respondents in the sample clearly points

4 Note that a privately egalitarian profile did not emerge from the data, indicating that few, if any, support gender equality in the home, but not in public. 
to its conceptual importance as well. More needs to be done to understand this gender ideology profile, including the ways that these attitudes are formed and their social and psychological impact. Ongoing research should also determine whether the publicly egalitarian profile transcends the Guatemalan context. Do people hold these same patterns of gender attitudes in the West or in other developing nations? What other profiles may emerge?

In addition to demonstrating a new way to analyze and conceptualize gender attitudes, this study breaks new ground by considering the effect of religious schools. While a number of studies have demonstrated a strong link between education and gender egalitarianism, little, if any, attention has been given to the effect that religious schools have on gender attitude formation. Wider studies on religion and gender would suggest that secular schools would be more gender egalitarian than religious schools (Davis and Greenstein 2009). The results in this study reveal a different picture. In fact, Catholic schools in Guatemala tend to be the most egalitarian, and evangelical schools are not significantly distinguishable from secular schools in gender attitudes when relevant controls are added. These findings draw attention to the need for more studies on religious schools with special emphasis on the factors that contribute to Catholic schools' more egalitarian outcomes. It is also important to note that the cross-sectional nature of this study means that while there are clear associations in this analysis between the gender attitude profiles and the different types of religious and secular schools, it is not possible to determine the specific effect of these school types without contributions from additional longitudinal and qualitative studies. These specific effects could also be the focus of future studies.

Next, this study provides more insight into the link between religion and gender egalitarianism. The above noted difference between Catholic and evangelical schools in Guatemala again demonstrates that different religious perspectives are correlated with differing gender outcomes. The Catholic findings show that schools from this religious tradition are associated with more gender egalitarian attitudes. In contrast, this study finds a strong association between evangelicals (and traditional evangelical beliefs) and a different profile of gender attitudes, which I call public egalitarianism. This publicly egalitarian profile would explain some of the contradictory findings about Latin evangelicals' gender attitudes. Researchers like Steigenga and Smilde (1999), who focus on women's social rights and participation, find no difference or perhaps even a positive association between evangelicalism and gender egalitarianism, whereas those such as Gill (1990), who include the domestic and religious spheres in their analysis, point to the non-egalitarian nature of evangelicalism. This again demonstrates the importance of using latent class profiles for gender ideology research because these profiles provide more nuanced measures to help us more clearly understand distinct differences in gender attitudes.

Finally, this study reexamines a number of well-established theories about gender attitude formation. First, it reaffirms previous findings that females hold more egalitarian perspectives than males. It also supports the well-established theory that those with more education tend to be more egalitarian. Surprisingly, this study finds no correlation between students' gender attitudes and their mothers' education levels or workforce participation. While the link between female education and workforce participation is documented around the world, the transmission of gender attitudes from mother to daughter has mainly been studied in Western contexts (Davis and Greenstein 2009). Perhaps this process works differently in Latin contexts. This also warrants further research.

This study set out to examine gender attitudes in a very specific context-Guatemalan private and especially private religious schools. As such, it contributes new insight into Guatemalan children's attitudes and beliefs. It also shows the relationships between secular and religious Guatemalan schools and gender attitudes. Although the findings in this study are significant in their own right, they also point to promising new directions for broader research. They show the importance of using new methods to develop more multidimensional profiles of gender attitudes. They highlight the significant role that religious schools can have in gender attitude formation, and they provide a more nuanced 
picture of religion's effect on gender attitudes. Each of these important topics deserves more attention in future scholarly work.

Funding: This research received no external funding.

Conflicts of Interest: The author declares no conflict of interest.

\section{References}

Barnett, Rosalind, and Caryl Rivers. 2004. Same Difference: How Gender Myths Are Hurting Our Relationships, Our Children, and Our Jobs. Cambridge: Basic Books.

Bartkowski, John P., and Lynn M. Hempel. 2009. Sex and Gender Traditionalism among Conservative Protestants: Does the Difference Make a Difference? Journal for the Scientific Study of Religion 48: 805-16. [CrossRef]

Blair, Sampson L., and Daniel T. Lichter. 1991. Measuring the Division of Household Labor: Gender Segregation of Housework among American Couples. Journal of Family Issues 12: 91-113. [CrossRef]

Bolzendahl, Catherine I., and Daniel J. Myers. 2004. Feminist Attitudes and Support for Gender Equality: Opinion Change in Women and Men, 1974-1998. Social Forces 83: 759-90. [CrossRef]

Brusco, Elizabeth. 1993. The reformation of machismo: Asceticism and masculinity among Colombia evangelicals. In Rethinking Protestantism in Latin America. Edited by Virginia Garrard-Burnett and David Stoll. Philadelphia: Temple University Press.

Chozick, Amy. 2002. Born Again in Guatemala: The Politics of Protestantization. Common Dreams. Available online: https:/ /archive.commondreams.org/scriptfiles/views02/0815-05.htm (accessed on 19 July 2018).

Cole, Elizabeth R., and Alyssa N. Zucker. 2007. Black and White Women's Perspectives on Femininity. Cultural Diversity and Ethnic Minority Psychology 13: 1-9. [CrossRef] [PubMed]

Corrigall, Elizabeth A., and Alison M. Konrad. 2007. Gender Role Attitudes and Careers: A Longitudinal Study. Sex Roles 56: 847-55. [CrossRef]

Cox, Harvey. 1995. Fire from Heaven: The Rise of Pentecostal Spirituality and the Reshaping of Religion in the Twenty-First Century. New York: Addison-Wesley.

Cunningham, Mick, Ann M. Beutel, Jennifer S. Barber, and Arland Thornton. 2005. Reciprocal Relationships between Attitudes about Gender and Social Contexts during Young Adulthood. Social Science Research 34: 862-92. [CrossRef]

Davis, Shannon N. 2007. Gender Ideology Construction from Adolescence to Young Adulthood. Social Science Research 36: 1021-41. [CrossRef]

Davis, Shannon N., and Theodore N. Greenstein. 2009. Gender Ideology: Components, Predictors, and Consequences. Annual Review of Sociology 35: 87-105. [CrossRef]

Edgell, Penny, Darin Mather, and Eric Tranby. 2013. Profiles of Anticipated Support: Religion's Place in the Composition of Americans' Emotional Support Networks. Journal for the Scientific Study of Religion 52: 293-308. [CrossRef]

Fan, Pi-Ling, and Margaret Mooney Marini. 2000. Influences on Gender-role Attitudes during the Transition to Adulthood. Social Science Research 29: 258-83. [CrossRef]

Fuwa, Makiko. 2004. Macro-level Gender Inequality and the Division of Household Labor in 22 Countries. American Sociological Review 69: 751-67. [CrossRef]

Garrard-Burnett, Virginia. 1998. Protestantism in Guatemala: Living in the New Jerusalem. Austin: University of Texas Press.

Gibbons, Judith L., Beverly A. Hamby, and Wanda D. Dennis. 1997. Researching Gender-role Ideologies Internationally and Cross-culturally. Psychology of Women Quarterly 21: 151-70. [CrossRef]

Gibbons, Judith L., Samantha L. Wilson, and Christine A. Rufener. 2006. Gender Attitudes Mediate Gender Differences in Attitudes toward Adoption in Guatemala. Sex Roles 54: 139-45. [CrossRef]

Gill, Lesley. 1990. 'Like a Veil to Cover Them': Women and the Pentecostal Movement in La Paz. American Ethnologist 17: 708-21. [CrossRef]

Greenstein, Theodore N. 1996. Husbands' Participation in Domestic Labor: Interactive Effects of Wives' and Husbands' Gender Ideologies. Journal of Marriage and Family 58: 585-95. [CrossRef]

Grieve, Norma, Doreen Rosenthal, and Antoniette Cavallo. 1988. Self-esteem and Sex-role Attitudes: A Comparison of Italian- and Anglo-Australian Adolescent Girls. Psychology of Women Quarterly 12: 175-89. [CrossRef] 
Hoffman, John P., and John P. Bartkowski. 2008. Gender, Religious Tradition and Biblical Literalism. Social Forces 86: 1245-72. [CrossRef]

Inglehart, Ronald, and Pippa Norris. 2003. Rising Tide: Gender Equality and Cultural Change around the World. New York: Cambridge University Press.

Inter-Parliamentary Union (IPU). 1997. Men and Women in Politics: Democracy Still in the Making. Geneva: Inter-Parliamentary Union.

Kamo, Yoshinori. 1988. Determinants of Household Division of Labor: Resources, Power, and Ideology. Journal of Family Issues 9: 177-200. [CrossRef] [PubMed]

Kaufman, Gayle. 2000. Do Gender Role Attitudes Matter? Family Formation and Dissolution among Traditional and Egalitarian Men and Women. Journal of Family Issues 21: 128-44. [CrossRef]

King, Lynda A., Daniel W. King, David M. Gudanowski, and Casey T. Taft. 1997. Latent Structure of the Sex-role Egalitarianism Scale: Confirmatory Factor Analyses. Sex Roles 36: 221-34. [CrossRef]

Levant, Ronald, Katherine Richmond, Stephen Cook, A. Tanner House, and Maryse Aupont. 2007. The Femininity Ideology Scale: Factor Structure, Reliability, Convergent and Discriminant Validity, and Social Contextual Variation. Sex Roles 57: 373-83. [CrossRef]

Lokesh, P. Nijhawan, Manthan D. Janodia, B. S. Muddukrishna, K. M. Bhat, K. L. Bairy, N. Udupa, and Prashant B. Musmade. 2013. Informed Consent: Issues and Challenges. Journal of Advanced Pharmaceutical Technology E Research 4: 134-40.

Mariz, Cecilia Loreto. 1994. Coping with Poverty: Pentecostals and Christian Base Communities in Brazil. Philadelphia: Temple University Press.

Mariz, Cecilia Loreto, and Dores Campos Machado. 1997. Pentecostalism and Women in Brazil. In Power, Politics, and Pentecostals in Latin America. Edited by Edward L. Cleary and Hannah W. Stewart-Gambino. Boulder: Westview Press.

Marquardt, Marie Friedmann. 2005. From Shame to Confidence: Gender, Religious Conversion, and Civic Engagement of Mexicans in the U.S. South. Latin American Perspectives 140: 27-56. [CrossRef]

Martin, David. 1990. Tongues of Fire: The Explosion of Protestantism in Latin America. Cambridge: Basil Blackwell.

Martin, David. 2002. Pentecostalism: The World Their Parish. Malden: Blackwell.

Mather, Darin M. 2015a. A Higher Calling? Academic Aspirations in Guatemalan Religious Schools. Global Journal of Human Social Science 15: 13-23.

Mather, Darin M. 2015b. Faith in Yourself: Girls' Self-Esteem and Self-Confidence in Guatemalan Religious Schools. International Journal of Sociology of Education 4: 69-97.

McCutcheon, Alan L. 1987. Quantitative Applications in the Social Sciences \#64: Latent Class Analysis. London: Sage Publications.

McDaniel, Anne E. 2008. Measuring Gender Egalitarianism: The Attitudinal Difference between Men and Women. International Journal of Sociology 38: 58-80. [CrossRef]

McDaniel, Anne. 2010. Cross-national Gender Gaps in Educational Expectations: The Influence of National-level Gender Ideology and Educational Systems. Comparative Education Review 54: 27-50. [CrossRef]

Milo, Tamar, Lee W. Badger, and Deborah R. Coggins. 1983. Conceptual Analysis of the Sex-role Ideology Scale. Psychological Reports 53: 139-46. [CrossRef]

MINEDUC. 2007. Annual Education Statistics. Ministry of Education, Government of Guatemala. Available online: http:/ / www.mineduc.gob.gt/estadistica/2008/anuario/main.html (accessed on 11 March 2015).

MINEDUC. 2008. Educational Establishments of Sacatepequez. Guatemala: The Ministry of Education, Department of Sacatepequez, Guatemala.

Nussbaum, Martha C. 2000. Women and Human Development: The Capabilities Approach. Cambridge: Cambridge University Press.

O'Neill, Kevin Lewis. 2010. City of God: Christian Citizenship in Postwar Guatemala. Berkeley: University of California Press.

Ossana, Shelly M., Janet E. Helms, and Mary M. Leonard. 1992. Do ‘Womanist' Identity Attitudes Influence College Women's Self-esteem and Perception of Environmental Bias? Journal of Counseling and Development 70: 402-8. [CrossRef]

Paxton, Pamela, and Melanie M. Hughes. 2015. Women, Politics, and Power: A Global Perspective. Washington, DC: CQ Press.

Paxton, Pamela, and Sheri Kunovich. 2003. Women's Political Representation: The Importance of Ideology. Social Forces 82: 87-114. [CrossRef] 
Peek, Charles W., George D. Lowe, and Susan Williams. 1991. Gender and God's Word: Another Look at Religious Fundamentalism and Sexism. Social Forces 69: 1205-21. [CrossRef]

Price, Anne M. 2008. Colonial History, Muslim Presence, and Gender Equity Ideology: A Cross-national Analysis. International Journal of Sociology 38: 81-103. [CrossRef]

Raudenbush, Stephen, and Anthony S. Bryk. 2002. Hierarchical Linear Models: Applications and Data Analysis Methods, 2nd ed. Thousand Oaks: Sage.

Rodríguez, Jeyle Ortiz, and Vijayan Kumara Pillai. 2017. Advancing Support for Gender Equality among Women in Mexico: Significance of Labor Force Participation. International Social Work 1-13. [CrossRef]

Ruiz, Andrea L., John P. Bartkowski, Christopher G. Ellison, Gabriel A. Acevedo, and Xiaohe Xu. 2017. Religion and Gender Ideologies among Working-Age U.S. Latinas/os. Religions 8: 121. [CrossRef]

Sherman, Amy L. 1997. The Soul of Development: Biblical Christianity and Economic Transformation in Guatemala. New York: Oxford University Press.

Silverstein, Merril, and Vern L. Bengston. 1997. Intergenerational Solidarity and the Structure of Adult Child-parent Relationships in American Families. American Journal of Sociology 103: 429-60. [CrossRef]

Spence, Janet T. 1993. Gender-related Traits and Gender Ideology: Evidence for a Multifactorial Theory. Journal of Personality and Social Psychology 64: 624-35. [CrossRef] [PubMed]

Spence, Janet T., and Camille E. Buckner. 2000. Instrumental and Expressive Traits, Trait Stereotypes, and Sexist Attitudes: What Do They Signify? Psychology of Women Quarterly 24: 44-53. [CrossRef]

Steigenga, Timothy J., and David A. Smilde. 1999. Wrapped in the Holy Shawl: The Strange Case of Conservative Christians and Gender Equality in Latin America. In Latin American Religion in Motion. Edited by Christian Smith and Joshua Prokopy. New York: Routledge.

Sutfin, Erin L., Megan Fulcher, Ryan P. Bowles, and Charlotte J. Patterson. 2008. How Lesbian and Heterosexual Parents Convey Attitudes about Gender to their Children: The Role of Gendered Environments. Sex Roles 58: 501-13. [CrossRef]

Tallichet, Suzanne E., and Fern K. Willits. 1986. Gender-role Attitude Change of Young Women: Influential Factors from a Panel Study. Social Psychology Quarterly 49: 219-27. [CrossRef]

Thornton, Arland, Duane F. Alwin, and Donald Camburn. 1983. Source Causes and Consequences of Sex-role Attitudes and Attitude Change. American Sociological Review 48: 211-27. [CrossRef] [PubMed]

Vermunt, Jeroen K. 2010. Latent Class Modeling with Covariates: Two Improved Three-step Approaches. Political Analysis 18: 450-69. [CrossRef]

Vermunt, Jeroen K., and Jay Magidson. 2004. Latent Class Analysis. In The Sage Encyclopedia of Social Sciences Research Methods. Edited by Michael S. Lewis-Beck, Alan E. Bryman and Tim F. Liao. Thousand Oakes: Sage Publications.

Vermunt, Jeroen K., and Jay Magidson. 2005. Latent Gold 4.0 User's Guide. Belmont: Statistical Innovations Inc. 